\title{
Hubungan Antara Usia Dengan Ukuran Tonsil Pada Tonsilitis Kronis Di Rumah Sakit Islam Siti Rahmah Padang Sumatera Barat Pada Tahun 2017 - 2018
}

\author{
Zuhdi, $\mathrm{M}^{1}$, Triola Asman, $\mathrm{S}^{2}$, Teti Vani, $\mathrm{A}^{3}$
}

\footnotetext{
${ }^{1}$ Mahasiswa Fakultas Kedokteran Universitas Baiturrahmah

Email : muhammadzuhdi15@yahoo.com

${ }^{2}$ Bagian THT Fakultas Kedokteran Universitas Baiturrahmah

${ }^{3}$ Bagian Histologi Fakultas Kedokteran Universitas Baiturrahmah
}

\begin{abstract}
Abstrak
Latar Belakang:Tonsilitis kronis adalah peradangan tonsil yang menetap sebagai akibat infeksi akut atau subklinis yang berulang. Ukuran tonsil pada tonsilitis kronis membesar akibat hiperplasia parenkim atau degenerasi fibrinoid dengan obstruksi kripta tonsil. Berdasarkan data dari Departemen Kesehatan RI tahun 2012, angka kejadian penyakit tonsilitis di Indonesia sekitar 23\%. Berdasarkan data epidemiologi penyakit THT di tujuh provinsi di Indonesia pada bulan September tahun 2012, prevalensi tonsillitis kronik sebesar 3,8\%. Tujuan penelitian adalah mengetahui hubungan usia dengan ukuran tonsil pada tonsilitis kronik di Rumah Sakit Siti Rahmah Padang Sumatera Barat tahun 2017 - 2018.Metode: Penelitian ini menggunakan data sekunder yaitu rekam medis di RSI Siti Rahmah Padang 2017 - 2018. Penelitian dan pengumpulan data dilaksanakan pada bulan November 2018- Mei 2019 di instalasi THT-KL RSI Siti Rahmah Padang. Penelitian ini merupakan studi analitik. Populasi adalah pasien tonsilitis kronik di instalasi THT-KL RSI Siti Rahmah tahun 2017 - 2018 sebanyak 66 pasien. Analisis data adalah univariat disajikan dalam bentuk tabel distribusi frekuensi dan analisis bivariat menggunakan uji spearman rho dengan menggunakan program SPSS versi 24.0. Hasil: Berdasarkan penelitian sebanyak $(57,6 \%)$ adalah wanita dan $(42,4 \%)$ adalah laki-laki, paling banyak berada pada usia $\leq 18$ tahun yaitu $(72.7 \%)$, paling banyak dengan ukuran tonsil hipertropi yaitu (65.2\%) dan terdapat hubungan usia dengan ukuran tonsilitis pada tonsilitis kronik diRumah Sakit Siti Rahmah Padang Sumatera Barat tahun 2017 $2018 \mathrm{p}=0,000(\mathrm{p}<0,05)$. Kesimpulan: Terdapat hubungan usia dengan ukuran tonsilitis pada tonsilitis kronik diRumah Sakit Siti Rahmah Padang Sumatera Barat tahun 2017 - 2018.
\end{abstract}

\section{Kata Kunci -- Jenis Kelamin, Usia, Ukuran Tonsil}

\begin{abstract}
Background: Chronic tonsillitis is tonsillar inflammation that is defined as a result of repeated acute or subclinical infection. The tonsillar size in chronic tonsillitis causes parenchymal hyperplasia or fibrionoid degeneration with tonsillar crypt obstruction, based on data from the Indonesian Ministry of Health in 2012, the incidence of tonsillitis in Indonesia is around 23\%. Based on epidemiology of ENT disease in seven provinces in Indonesia in September 2012, the prevalence of chronic tonsillitis was 3.8\%. Objective: To determine the relationship between age and size of tonsil in chronic tonsillitis in Siti Rahmah Hospital, Padang, West Sumatra, 2017 - 2018. Method: This study uses secondary data, namely medical records at Siti Rahmah Hospital in Padang 2017 - 2018, research and data collection was conducted in November 2018 - May 2019. Result: The study was conducted at the ENT-KL installation at RSI Siti Rahmah Padang, this study is a form of study analytic, population is chronic tonsillitis patients at ENT-KL installation RSI Siti Rahmah in 2017 - 2018
\end{abstract}




\section{Heme, Vol II No 1}

January 2020

as many as 66 patients, analyzing data is univariate presented in the form of frequency distribution tables and bivariate analysis using spearman rho test using SPSS version 24.0. Based on the study (57.6\%) were women and $(42.4 \%)$ were men, most at the age $\leq 18$ years $(72.7 \%)$, the most with the size of the hypertrophy tonsil $(65.2 \%)$ and there was a relationship between age and size of tonsillitis in chronic tonsillitis in Siti Rahmah Hospital Padang West Sumatra in $2017-2018 p=0,000$ ( $p<0.05)$ Conclusion:. There is a relationship between age and size of tonsillitis in chronic tonsillitis in Siti Rahmah Hospital, Padang, West Sumatra, 2017 2018.

Keywords -- Gender, Age, Tonsil Size

Email : heme@unbrah.ac.id 


\section{Pendahuluan}

Tonsilitis kronis merupakan penyakit yang paling sering terjadi dari semua penyakit tenggorok yang berulang. Tonsilitis kronis umumnya terjadi akibat komplikasi tonsilitis akut, terutama yang tidak mendapat terapi adekuat. Selain pengobatan yang tidak adekuat, faktor predisposisi timbulnya tonsilitis kronis lain adalah higien mulut yang buruk, kelelahan fisik dan beberapa jenis makanan. ${ }^{1-3}$

Gejala umum tonsilitis kronis yaitu sakit tenggorok, disfagia, dan demam. Penyakit tonsil mempengaruhi struktur terkait anatomi lainnya seperti celah telinga tengah, sinus paranasal, dan gabungan saluran pernafasan dengan bagian atas saluran pencernaan. Anak-anak yang mengalami tonsilitis kronis memiliki pembesaran tonsil dan pembuluh darah membesar pada permukaan tonsil. ${ }^{4}$

Peradangan tonsil akan mengakibatkan pembesaran yang menyebabkan kesulitan menelan atau seperti ada yang mengganjal di tenggorok. Pada anak biasanya keadaan ini juga dapat mengakibatkan keluhan berupa ngorok saat tidur karena pengaruh besarnya tonsil mengganggu pernafasan bahkan keluhan sesak nafas juga dapat terjadi apabila pembesaran tonsil telah menutup jalur pernafasan. Jika peradangan telah ditanggulangi, kemungkin tonsil kembali pulih seperti semula atau bahkan tidak dapat kembali sehat seperti semula. Apabila tidak terjadi penyembuhan yang sempurna pada tonsil, dapat terjadi infeksi berulang. Apabila keadaan ini menetap, bakteri patogen akan bersarang di dalam tonsil dan terjadi peradangan yang kronis atau yang disebut dengan tonsilitis kronis. ${ }^{5}$

Ukuran tonsil terbagi 5 mulai dari T0-T0, T1-T1, T2-T2, T3-T3, dan T4-T4. Ukuran T0-T0 memiliki arti tidak ada pembesaran tonsil atau atropi dan tanpa obstruksi udara. Ukuran T1-T1 memiliki arti sedikit keluar dimana ukuran tonsil $<25 \%$ dari diameter orofaring yang di ukur dari plika anterior kiri dan kanan. Ukuran T2-T2 memiliki arti tonsil $>25 \%$ s/d $<50 \%$ dari diameter orofaring yang di ukur dari plika anterior kiri dan kanan. Ukuran T3-T3 memiliki arti tonsil $>50 \%$ s/d $<75 \%$ dari diameter orofaring yang di ukur dari plika anterior kiri dan kanan. Ukuran T4-T4 memiliki arti tonsil $>75 \%$ dari diameter orofaring yang di ukur dari plika anterior kiri dan kanan. ${ }^{6}$

Banyaknya faktor predisposisi timbulnya tonsilitis kronis juga berdampak pada banyaknya angka kejadian tonsilitis kronis. Seperti halnya pada penelitian Khan et al di RS Khyber Peshawar Pakistan pada periode April 2011 sampai dengan Mei 2012, dilakukan analisis tentang distribusi penyakit Telinga Hidung Tenggorok (THT) dan didapatkan 8980 orang menderita tonsilitis kronis $(27,37 \%)$ dari 32.800 total sampel. Dalam penelitian ini tonsilitis kronis berada di urutan teratas dari insiden penyakit THT lainnya. Tarasov dan Morozov juga melakukan pemeriksaan kesehatan pada anak dan dewasa, mendapatkan total penyakit THT berjumlah 190-230 per 1.000 penduduk, dan $38,4 \%$ di antaranya menderita penyakit tonsilitis kronis. ${ }^{7,8}$

World Health Organization tahun 2013 memperkirakan jumlah kasus tonsilitis kronis 287.000 anak dibawah 15 tahun. ${ }^{9}$ Penelitian yang dilakukan di Rumah Sakit Sarawak di Malaysia pada periode Juli 2003 sampai Juni 2004, dari 657 penderita tonsilitis kronis didapatkan pria sebesar 342 $(52 \%)$ dan wanita $315(48 \%) .{ }^{10}$

Berdasarkan data dari Departemen Kesehatan RI tahun 2012 , angka kejadian penyakit tonsilitis di Indonesia sekitar $23 \%$. Berdasarkan data epidemiologi penyakit THT di tujuh provinsi di Indonesia pada bulan September tahun 2012, prevalensi tonsillitis kronik sebesar 3,8\%. ${ }^{11}$ Menurut Nurjannah tahun 2011, distribusi proporsi penderita tonsillitis kronis di Medan pada tahun 2007 - 2010 berdasarkan usia terjadi paling banyak pada kelompok usia $11-20$ 
tahun yaitu sebesar $40 \%$. Berdasarkan jenis kelamin terbanyak pada pria yaitu 18 sample $51,4 \%$ dan ukuran tonsil T3 sebesar $47,1 \% .^{12}$

Berdasarkan data rekam medis tahun 2010 di RSUP dr. M. Djamil Padang bagian Poliklinik THT-KL sub bagian laring faring ditemukan tonsillitis sebanyak 465 dari 1110 kunjungan. Angka kejadian tonsilitis kronis meningkat dari tahun ke tahun. Insiden tonsilitis kronis banyak terjadi pada anak. ${ }^{13}$

Penelitian yang dilakukan oleh Shalihat tahun 2013 didapatkan 149 penderita tonsilitis kronis dari data rekam medis RSUP Dr. M. Djamil Padang. distribusi frekuensi penderita tonsilitis kronis terbanyak berdasarkan usia pada kelompok usia 11-20 tahun 70 penderita $(47,0 \%)$, jenis kelamin wanita 84 penderita $(56,4 \%)$, ukuran tonsil T3-T3 82 penderita $(55 \%){ }^{14}$

Hubungan usia dengan ukuran tonsil dapat dilihat dari aktivitas imunologi tonsil. Respon imun selular pada tonsilitis kronis menunjukkan terjadinya peningkatan deposit antigen pada jaringan tonsil. Hal ini menyebabkan peningkatan regulasi sel-sel imunokompeten yang terjadi terus-menerus. Hal ini dibuktikan dengan adanya peningkatan insidensi sel yang mengekspresikan IL-1 $\beta$, TNF- $\alpha$, IL-6, IL-8, IL-2, INF- $\gamma$, IL-10 dan IL-4. Banyak ditemukan antara usia 3 hingga 10 tahun, akibatnya tonsil lebih menonjol selama periode ini dan kemudian menunjukkan involusi bergantung usia. Satu atau lebih serangan tonsilitis akut per tahun umum terjadi pada anak-anak kelompok usia sekolah dasar. $^{4}$

Beberapa peneliti menduga bahwa tonsil dan adenoid membesar pada usia anak-anak. Penelitian dengan menggunakan Magnetic Resonance Imagine (MRI) memperlihatkan tonsil dan adenoid berkembang secara proporsional pada struktur organ selama perkembangan normal anak. ${ }^{4}$ Hubungan usia dengan ukuran tonsil dapat di lihat dari penelitian Shalihat dimana tonsil hipertrofi lebih banyak ditemukan pada penderita tonsilitis kronis yang berusia $\leq 18$ tahun yaitu sebanyak 89 penderita $(84,8 \%)$ sedangkan tonsil non hipertrofi banyak ditemukan pada usia $>18$ tahun yaitu $21(47,7 \%)$. Setelah dilakukan uji statistik dengan analisis chisquare diperoleh nilai p sebesar $0,000 .{ }^{13} \mathrm{Hal}$ serupa juga diperoleh dari penelitian Amalia yang mendapatkan $\mathrm{p}=0,001$ yang menunjukkan terdapat hubungan yang bermakna antara usia dengan ukuran tonsil pada penderita tonsilitis kronis. ${ }^{16}$

Berdasarkan penjelasan diatas maka peneliti tertarik untuk melakukan penelitian mengenai hubungan usia dan ukuran tonsil dengan kejadian tonsilitis kronis di RSI Siti Rahmah Padang tahun 2017 - 2018.

\section{Metode Penelitian}

Penelitian ini menggunakan data sekunder yaitu rekam medis di RSI Siti Rahmah Padang 2017 - 2018. Penelitian ini dibatasi pada variabel jenis kelamin, usia dan ukuran tonsil pada tonsilitis kronis. Penelitian dan pengumpulan data dilaksanakan pada bulan november 2018- Mei 2019. Penelitian dilakukan di instalasi THT-KL RSI Siti Rahmah Padang. Penelitian ini merupakan suatu bentuk studi analitik. Penelitian ini digunakan untuk mencari hubungan antara variabel bebas dengan variabel terikat dengan melakukan pengukuran sesaat. Populasi pada penelitian ini adalah pasien yang terdapat di instalasi THT-KL RSI Siti Rahmah tahun 2017 - 2018, dan populasi terjangkau adalah pasien tonsilitis kronis di instalasi THT-KL RSI Siti Rahmah tahun 2017 - 2018. Kriteria inklusi pada penelitian ini adalah pasien yang didiagnosis tonsilitis kronis dan kriteria eksklusi adalah pasien yang didiagnosis tonsilitis kronis dengan komplikasi. Sampel pada penelitian ini dipilih dengan menggunakan metode probabilitas yaitu simple random sampling. 
Jumlah sampel yang didapatkan sebanyak 56 orang.

\section{HASIL}

Tabel 5.1 Distribusi Frekuensi Usia Pasien TONSILlitis Kronis di RSI Siti RahMah Padang TAHUN 2017 - 2018

\begin{tabular}{lcc}
\hline USIA & $\boldsymbol{F}$ & $\mathbf{\%}$ \\
\hline 0-10 Tahun & 22 & 33.3 \\
11-20 Tahun & 33 & 50.0 \\
21-30 Tahun & 6 & 9.1 \\
31-40 Tahun & 2 & 3.0 \\
41-50 Tahun & 2 & 3.0 \\
>50 Tahun & 1 & 1.5 \\
\hline JUMLAH & $\mathbf{6 6}$ & $\mathbf{1 0 0}$ \\
\hline
\end{tabular}

Berdasarkan tabel 5.1 diperoleh hasil dari 66 pasien tonsillitis kronis, paling banyak berada pada usia 11-20 tahun yaitu (50\%).

TABEL 5.2 DiSTRIBUSI FrEKUENSI KARAKTERISTIK PASIEN TONSIllitis KRONIS DI RSI Siti RAHMAH PADANG TAHUN 2017 - 2018

\begin{tabular}{llc}
\hline Jenis Kelamin & $\boldsymbol{F}$ & $\boldsymbol{\%}$ \\
\hline Pria & 28 & 42.4 \\
Wanita & 38 & 57.6 \\
\hline Jumlah & $\mathbf{6 6}$ & $\mathbf{1 0 0}$ \\
\hline
\end{tabular}

Berdasarkan tabel 5.2 diperoleh hasil dari 66 pasien tonsillitis, sebanyak $(57,6 \%)$ adalah wanita dan $(42,4 \%)$ adalah pria di RSI Siti Rahmah Padang tahun 2017 - 2018.

TABEL 5.3 Distribusi FrekUENSI UKURAN TONSILITIS PASIEN TONSILlitis KRONIS DI RSI SITI RAHMAH PADANG TAHUN 2017 - 2018

\begin{tabular}{lcc}
\hline Ukuran Tonsilitis & $\boldsymbol{F}$ & $\boldsymbol{\%}$ \\
\hline $\mathrm{T} 1 / \mathrm{T} 1$ & 9 & 13.6 \\
$\mathrm{~T} 2 / \mathrm{T} 2$ & 14 & 21.2 \\
$\mathrm{~T} 3 / \mathrm{T} 3$ & 27 & 40.9 \\
$\mathrm{~T} 4 / \mathrm{T} 4$ & 16 & 24.2 \\
\hline Jumlah & $\mathbf{6 6}$ & $\mathbf{1 0 0}$ \\
\hline
\end{tabular}

Berdasarkan tabel 5.3 diperoleh hasil dari 66 pasien tonsillitis kronis, paling banyak dengan ukuran tonsis T3/T3 yaitu $(40,9 \%)$.
Tabel. 5.4 Hubungan Usia Dengan Ukuran Tonsilitis Pada TonsiLitis KroniK Di RUMaH Sakit Siti Rahmah Padang Sumatera barat TAHUN 2017 - 2018

\begin{tabular}{|c|c|c|c|c|c|c|c|}
\hline \multirow{3}{*}{ Usia } & \multicolumn{4}{|c|}{ Ukuran Tonsil } & \multirow{2}{*}{\multicolumn{2}{|c|}{ Total }} & \multirow[b]{2}{*}{ P Value } \\
\hline & \multicolumn{2}{|c|}{$\begin{array}{l}\text { Non } \\
\text { Hipertropi }\end{array}$} & \multicolumn{2}{|c|}{$\begin{array}{l}\text { Hipertro } \\
\text { pi }\end{array}$} & & & \\
\hline & $\mathbf{F}$ & $\%$ & $\mathbf{F}$ & $\%$ & $\mathbf{F}$ & $\%$ & \\
\hline $\begin{array}{l}\leq 18 \\
\text { Tahun }\end{array}$ & 21 & 43.8 & 27 & 56.3 & 48 & 100 & \\
\hline $\begin{array}{l}>18 \\
\text { Tahun }\end{array}$ & 2 & 11.1 & 16 & 88.9 & 18 & 100 & 0.000 \\
\hline Total & 23 & 34.8 & 43 & 65.2 & 66 & 100 & \\
\hline
\end{tabular}

Berdasarkan tabel. 5.4 diperoleh pada usia $\leq$ 18 tahun ukuran tonsil paling banyak adalah Hipertropi yaitu (56.3\%), pada usia > 18 tahun ukuran tonsil paling banyak adalah Hipertropi yaitu (88.9\%). Hasil ini sudah dilakukan penggabungan sel dan dengan menggunakan uji spearman rho diperoleh nilai $p=0,000 \quad(p<0,05)$, maka dapat disimpulkan bahwa terdapat hubungan usia dengan ukuran tonsilitis pada tonsilitis kronik diRumah Sakit Siti Rahmah Padang Sumatera Barat tahun 2017 - 2018.

\section{Pembahasan}

\section{Usia}

Berdasarkan penelitian diperoleh hasil dari 66 pasien tonsillitis kronis, paling banyak berada pada usia 11-20 tahun yaitu (50\%) di RSI Siti Rahmah Padang tahun 2017 - 2018. Hasil penelitian ini mendukung penelitian sebelumnya yang dilakukan oleh Sapitri di RSUP Raden Mattaher Jambi tahun 2013, pasien Tonsilitis Kronis terbanyak pada kisaran usia 5 - 14 tahun (50\%). Penelitian Khasanov et al di Rusia mengenai prevalensi tonsilitis kronis pada keluarga, didapatkan 335 orang anak usia 1-15 tahun dari 321 keluarga mengalami penyakit tonsilitis kronis. ${ }^{17}$ Pada penelitian Sembiring et al tahun 2013 di poliklinik THT BLU RSUP Prof dr. R. D. Kandou didapatkan usia terbanyak yang menderita Tonsilitis Kronis yaitu usia $<12$ tahun. 
Pada usia sekolah, mulai dari usia 5 tahun, anak lebih rentan terkena infeksi virus dan bakteri dari lingkungan sekitar. Salah satu faktor predisposisi timbulnya tonsilitis kronis adalah pengaruh beberapa jenis makanan. Hal ini disebabkan karena anak mengkonsumsi makanan seperti makanan dengan pemanis buatan, mengandung banyak pengawet dan perawatan mulut yang tidak baik. $^{3}$

Fungsi imunologi tonsil sangat aktif antara usia 3-10 tahun. Fungsi tonsil akan meningkat pada usia 5 tahun kemudian menurun dan akan mengalami peningkatan lagi pada usia 10 tahun, kemudian akan menurun pada usia 15 tahun karena tonsil mulai mengalami involusi pada saat pubertas sehingga produksi antibodi berkurang yang membuat lebih rentan terhadap infeksi. Anak-anak dan remaja usia 5-15 tahun, yang lebih banyak menghabiskan waktu di lingkungan sekolah dan di luar ruangan, sering menderita ISPA. ${ }^{18}$

Tingginya kejadian tonsilitis kronis pada anak-anak dan remaja dikarenakan mereka sering menderita ISPA atau tonsilitis akut yang tidak diterapi dengan adekuat atau dibiarkan saja tanpa pengobatan. Tonsilitis dapat menyebar melalui kontak tangan maupun udara sehingga anak-anak dan remaja berusia 5-15 tahun adalah yang paling mungkin untuk menderita tonsilitis, tetapi dapat menyerang siapa saja, sehingga pada penelitian ini juga ditemukan penderita usia $<5$ tahun dan $>15$ tahun. ${ }^{19}$

\section{Jenis Kelamin}

Berdasarkan penelitian diperoleh hasil dari 66 pasien tonsillitis, sebanyak $(57,6 \%)$ adalah wanita dan $(42,4 \%)$ adalah pria di RSI Siti Rahmah Padang tahun 2017 - 2018. Hasil penelitian ini sejalan dengan penelitian sebelumnya yang dilakukan oleh Fakh, di Bagian THT-KL RSUP Dr. M. Djamil Padang juga diperoleh hasil paling banyak jenis kelamin pasien penderita tonsillitis adalah wanita yaitu $(56 \%) .{ }^{20}$ Penelitian yang dilakukan oleh Kishve et al, melakukan penelitian case series di India, dari 203 pasien tonsilitis dengan mayoritas usia 5-14 tahun lebih banyak berjenis kelamin wanita yakni sebanyak $105(51,72 \%)$, sedangkan pria sebanyak $98(48,28 \%){ }^{21}$

Hal ini sesuai dengan data dari prevalensi penyakit kronis Amerika Serikat, didapatkan rata-rata jumlah penderita tonsilitis kronis setiap tahunnya lebih banyak pada jenis kelamin wanita yakni sebanyak 13,7/1.000 penduduk sedangkan pria sebanyak 9/1.000 penduduk. ${ }^{1-3}$

Faktor predisposisi tonsilitis kronis antara lain iritasi kronis (akibat rokok dan makanan), gizi atau daya tahan tubuh yang rendah, pengaruh cuaca dan hiegine mulut yang buruk. Pada masa pubertas dimana kebutuhan kalori dan protein meningkat, wanita terutama usia remaja lebih mementingkan bentuk tubuh dan penampilan sehingga banyak dari mereka yang menunda jadwal makan bahkan mengurangi porsi makanan dari yang dianjurkan agar tampak sempurna postur tubuhnya. Hal ini dapat menyebabkan kekurangan gizi dan daya tahan tubuh terhadap serangan berbagai penyakit menjadi sangat rendah sehingga lebih banyak mengalami masalah kesehatan. $^{22}$

Akcay et al menyatakan bahwa jenis kelamin pria menjadi faktor risiko terjadinya hipertrofi tonsil. ${ }^{23}$ Hal ini dikarnakan oleh faktor iritasi kronis, kebiasaan merokok dan kebiasaan makan, yang menyebabkan infeksi berulang pada tonsil sehingga terjadi pembesaran tonsil. ${ }^{24}$

\section{Ukuran Tonsilitis}

Berdasarkan penelitian diperoleh hasil dari 66 pasien tonsillitis kronis, paling banyak dengan ukuran tonsis T3/T3 yaitu $(40,9 \%)$ di 
RSI Siti Rahmah Padang tahun 2017 - 2018. Hasil penelitian ini sejalan dengan penelitian sebelumnya yang dilakukan oleh Amalia tahun 2011 dari 812 penderita yang mendapatkan tindakan tonsilektomi. ${ }^{16} 341$ (42\%) dengan ukuran tonsil T3 dan penelitian yang dilakukan oleh Fakh 2013 juga diperoleh hasil ukuran tonsil pada anak yang paling banyak ditemukan pada penelitian ini yaitu ukuran $\mathrm{T} 3-\mathrm{T} 3(68 \%){ }^{20}$

Salah satu faktor pembesaran pada tonsil karena pengaruh infeksi pada tonsil. Ukuran tonsil membesar akibat hiperplasia parenkim atau degenerasi fibrinoid dengan obstruksi kripta tonsil. Infeksi yang berulang dan sumbatan pada kripta tonsil mengakibatkan peningkatan stasis debris maupun antigen di dalam kripta, juga terjadi penurunan integritas epitel kripta sehingga memudahkan bakteri masuk ke parenkim tonsil. Bakteri yang masuk ke dalam parenkim tonsil akan mengakibatkan terjadinya infeksi tonsil. Pada tonsilitis kronis bisa ditemukan bakteri yang berlipat ganda. Bakteri yang menetap di dalam kripta tonsil menjadi sumber infeksi yang berulang terhadap tonsil. ${ }^{25}$

Tonsil merupakan jaringan limfoid yang berperan membantu sistem imunitas. Pada tonsilitis kronis terjadi infeksi yang menetap atau berulang. Tonsil yang berulang kali terkena infeksi suatu saat tidak dapat membunuh semua kuman, akibatnya kuman bersarang di dalam tonsil (fokal infeksi). Adanya infeksi berulang dan fokal infeksi menyebabkan tonsil bekerja keras melawan kuman dengan memproduksi sel-sel imun yang banyak sehingga ukuran tonsil akan membesar dengan cepat melebihi ukuran normal. ${ }^{24}$ Pada tonsilitis kronis terjadi infiltrasi limfosit ke epitel permukaan tonsil. Peningkatan jumlah sel plasma di dalam subepitel maupun di dalam jaringan interfolikel. Hiperplasia dan pembentukan fibrosis dari jaringan ikat parenkim dan jaringan limfoid mengakibatkan terjadinya hipertrofi tonsil. ${ }^{26}$
Ukuran tonsil hipertrofi dapat menimbulkan berbagai keluhan dan gejala seperti rasa tidak nyaman atau rasa mengganjal di tenggorokan, kesulitan menelan dan terutama bisa menyebabkan obstruksi saluran nafas yang ditandai dengan tidur mendengkur, sering mengantuk, gelisah, perhatian kurang dan prestasi belajar menurun. Hal inilah yang biasanya mendorong pasien untuk mencari pengobatan. $^{24}$

\section{Hubungan Usia Dengan Ukuran Tonsilitis}

Berdasarkan tabel. 5.4 diperoleh pada usia $\leq$ 18 tahun ukuran tonsil paling banyak adalah Hipertropi yaitu (56.3\%), pada usia > 18 tahun ukuran tonsil paling banyak adalah Hipertropi yaitu (88.9\%). Hasil ini sudah dilakukan penggabungan sel dan dengan menggunakan uji spearman rho diperoleh nilai $p=0,000 \quad(p<0,05)$, maka dapat disimpulkan bahwa terdapat hubungan usia dengan ukuran tonsilitis pada tonsilitis kronik diRumah Sakit Siti Rahmah Padang Sumatera Barat tahun 2017 - 2018.

Hasil penelitian ini berbanding terbalik dengan penelitian sebelumnya yang dilakukan oleh Amalia, 2011 yang mendapatkan $\mathrm{p}=0,001$ yang menunjukkan terdapat hubungan yang bermakna antara usia dengan ukuran tonsil, ${ }^{16}$ dan penelitian Shalihat, 2013 yang juga memperoleh hasil hubungan yang bermakna antara usia dengan ukuran tonsil. Perbedaan hasil penelitian terdapat pada hubungan kemaknaan positif. Pada penelitian ini didapatkan semakin tinggi usia, semakin besar ukuran tonsil dengan hubungan bermakna $p=0,000$

Aktivitas imun tonsil paling maksimal antara usia 3 sampai 10 tahun, karena itu ukuran tonsil paling besar pada usia anak. Tonsil mulai mengalami involusi secara bertahap pada saat pubertas. ${ }^{13}$ Penelitian Akcay et al, didapatkan pada anak sekolah dengan ukuran tonsil T2 dan T3 menunjukkan penurunan jumlah sejalan dengan bertambahnya usia. ${ }^{23}$ 
Crombie dan Barr dalam Shalihat, 2013 menyatakan adanya kecenderungan ukuran tonsil relatif kecil pada usia $<7$ tahun dan membesar pada usia 7-15 tahun, sedangkan pada usia tua memiliki ukuran tonsil yang kecil. $^{14}$

Pada penelitian ukuran tonsil pada rentang usia 3-10 tahun, didapatkan ukuran T3-T3. Akan tetapi, ukuran ini membesar sesuai dengan peningkatan usia yang bertolak belakang dengan aktivitas imun tonsil. Hasil penelitian menunjukkan pada usia dewasa juga mengalami pembesaran tonsil dengan ukuran T3-T3 dan T4-T4.

Respon imun selular pada tonsilitis kronis menunjukkan terjadinya peningkatan deposit antigen pada jaringan tonsil. Hal ini menyebabkan peningkatan regulasi sel-sel imunokompeten yang terjadi terus-menerus. Hal ini dibuktikan dengan adanya peningkatan insidensi sel yang mengekspresikan IL-1 $\beta$, TNF- $\alpha$, IL-6, IL-8, IL-2, INF- $\gamma$, IL-10 dan IL-4, yang banyak ditemukan antara usia 3 hingga 10 tahun. Selama periode ini akibatnya tonsil lebih menonjol dan kemudian menunjukkan involusi bergantung usia. Satu atau lebih serangan tonsilitis akut per tahun umum terjadi pada anak-anak kelompok usia sekolah dasar. ${ }^{7}$

Tonsil mengalami involusi pada masa pubertas, tetapi hal ini dapat terhambat apabila jaringan dan sel tonsil tidak mengalami kerusakan permanen. Anak-anak yang mengalami tonsillitis akut dengan pengobatan yang adekuat beresiko lebih rendah untuk mengalami pembesaran tonsil dibandingkan dengan pasien yang mengalami tonsillitis berulang maupun tonsillitis kronis. Kerusakan sel dan jaringan tonsil pada tonsillitis kronis dapat bersifat sementara maupun permanen. Jaringan tonsil yang rusak permanen akan diganti dengan jaringan parut sehingga mengakibatkan tidak semua jaringan tonsil mengalami involusi. ${ }^{27}$
Penurunan kerja tonsil terjadi seiring pertambahan usia. Proses penuaan mengakibatkan penurunan kerja organ dan sensitivitas sistem imun salah satunya tonsil. Penurunan sensitivitas menyebabkan komponen imunitas tidak dapat membedakan sel normal dengan sel abnormal yang mengakibatkan tonsil tidak dapat mengerjakan fungsinya secara maksimal untuk menangkap dan mengumpulkan benda asing dengan efektif dan sebagai organ produksi antibodi dan sensitivitas sel Limfosit $\mathrm{T}$ dengan antigen spesifik. ${ }^{28}$ Penurunan sensitivitas ini menyebabkan bakteri mudah menginfeksi organ tonsil yang akan berujung pada reaksi inflamasi tonsil yang ditandai oleh pembesaran ukuran tonsil yang abnormal.

Ni made putri dkk menyatakan bahwa lama exposure penderita tonsillitis terhadap faktor resiko menyebabkan pembesaran tonsil. Oral hygine yang buruk menjadi salah satu faktor resiko pembesaran tonsil. Oral hygine yang buruk dapat meningkatkan resiko terkena tonsilits tanpa memandang usia dan jenis kelamin. Ditambah dengan penurunan immunitas tubuh seiring bertambah usianya, juga memberikan efek dalam pembesaran tonsil. Kombinasi dari dua hal tersebut dapat memberikan gambaran pembesaran tonsil T3-T4 pada usia dewasa maupun lansia. ${ }^{29}$

Merokok juga menyebabkan penurunan antibodi pada tonsil, fungsi tonsil yaitu apabila patogen menembus lapisan epitel maka sel-sel fagositosik mononuklear akan mengenal dan mengeliminasi antigen, sehingga terjadi gangguan fungsi sel-sel pertahanan tubuh. Kemudian partikel dalam asap rokok merangsang tonsil untuk memproduksi antigen, jika berlangsung terus menerus tonsil akan mengalami peradangan. ${ }^{30}$ Komponen toksik dalam rokok dapat mengiritasi jaringan lunak rongga mulut, dan menyebabkan terjadinya infeksi mukosa, memperlambat penyembuhan luka, menekan proliferasi osteoblas. ${ }^{31}$ 
Terapi antibiotik pada tonsillitis kronis sering gagal dalam mengurangi dan mencegah rekurensi infeksi, baik karena kegagalan penetrasi antibiotik ke dalam parenkim tonsil ataupun ketidaktepatan antibiotik dan yang dibiarkan begitu saja. Penggunaan antibiotik yang sembarangan atau tidak tepat penakarannya selain dapat menggagalkan terapi juga dapat menimbulkan resistensi. ${ }^{5,12}$ Resisten yang dimaksud adalah keadaan dimana kehidupan mikroba sama sekali tidak terganggu oleh kehadiran antibiotika, akibatnya bakteri terus berkembangbiak dan menyebabkan hipertrofi tonsillitis kronis yang disebabkan infeksi berulang.

\section{KESIMPULAN DAN SARAN}

Berdasarkan hasil penelitian tentang hubungan usia dengan ukuran tonsilitis pada tonsilitis kronik di Rumah Sakit Siti Rahmah Padang Sumatera Barat tahun 2017 - 2018, maka dapat disimpulkan bahwa Penderita tonsillitis kronis terbanyak adalah wanita sebanyak ( $57,6 \%$ ). Paling banyak mengalami tonsillitis berada pada usia 11-20 tahun yaitu $(50 \%)$. Paling banyak memiliki ukuran tonsil T3/T3 yaitu (40,9\%). Terdapat hubungan usia dengan ukuran tonsilitis pada tonsilitis kronis diRumah Sakit Siti Rahmah Padang Sumatera Barat tahun 2017 - 2018 $\mathrm{p}=0,000(\mathrm{p}<0,05)$. Saran dari peneliti adalah masyarakat diharapkan dapat meningkatkan kepedulian tentang pentingnya kebersihan mulut dan pengetahuan tentang cara pemakaian antibiotik sesuai arahan dokter.

Bagi peneliti selanjutnya diharapkan hasil penelitian sebagai ilmu pengetahuan berupa sumber informasi dan diharapkan untuk penelitian selanjutnya dapat mengadakan peelitian mencari faktor resiko pembesaran tonsil pada usia dewasa.

\section{Daftar Pustaka}

[1] Adams GL, Lawrence RB, Peter AH. BOIES. 1997. Buku Ajar Penyakit THT (terjemahan). Edisi Ke-6. Jakarta: EGC.
[2] Amarudin T, Anton C. 2007. Kajian manfaat tonsilektomi. Cermin Dunia Kedokteran., No.155, p : 61-8.

[3] Soepardi, Arsyad .E., Iskandar Nurbaiti, Bashiruddin Jenny dan Restuti Dwi Ratna .2007. Buku Ajar Ilmu Kesehatan Telinga Hidung Tenggorok KepalaLeher. Edisi 6. Jakarta: Fakultas Kedokteran Universitas Indonesia.

[4] Kalaiarasi R, Subramanian KS, Vijayakumar C, Venkataramanan R. 2018. Micribiological Profile of Chronic Tonsillitis in the Pediatric Age Group. Available

from:https://www.cureus.com/articles/15137microbiological-profil-of-chronic-tonsillitis-inthe-pediatric-age-group

[5] Brodsky L, Poje C. Tonsillitis, tonsillectomy, and adenoidectomy. 2006. Dalam: Bailey BJ, Johnson JT, Newlands SD. Head and Neck Surgery Otolaryngology. Philadelpia: Lippincott Williams \& Wilkins.

[6] R Alfredo, Juares JC Antonio,et al. 2005. Histological Analysis of Tonsillectomy and Adenoidectomy specimens - January 2001 to May 2003. Rev Bras Otorrinolaringol.71 (1). P: $18-22$.

[7] Khan AR, Khan SA, Arif AU, Waheed R. 2013. Analysis of ENT diseases at Khyber teaching hospital, Peshawar. J. Med. Sci.

[8] Tarasov DI, Morozov AB. 1991. Frequency and structure of chronic disease of ear, throat and nose among population and their dinamycs. Vestn Otorino laryngology.

[9] World health organization, 2013. Survailance of risk factors for non-communicable diseases : the WHO stepiseapproach.summari. Geneva.

[10] Sing TT. 2007. Pattren of otorhinolaryngology head and neck disease in outpatient clinic of a Malaysian hospital. Journal of Head and Neck Surgery.

[11]Farokah, Suprihati, suyitno. 2007. Hubugan Tonsilitis kronik dengan prestasi belajar pada siswa kelas II Sekolah Dasar di kota Semarang. Cermin Dunia Kedokteran;155:87-91.Depkes RI. 2013. Tonsilektomi pada anak dan dewasa. Jakarta.

[12]Nurjannah Z. 2011. Karakteristik Penderita Tonsilitis Kronis Di RSUP Adam Malik Medan Tahun 2007 - 2010. Universitas Sumatera Utara.

[13] Novialdi N, Pulungan MR. 2010. Mikrobiologi tonsilitiskronis. Padang: Fakultas Kedokteran Universitas Andalas. Padang.

[14] Shalihat AO. 2015. Hubungan Usia, Jenis Kelamin dan Perlakuan Penatalaksanaan dengan Ukuran Tonsil pada Penderita Tonsilitis Kronis di Bagian THT-KL RSUP DR. M. Djamil Padang Tahun 2013. Jurnal kesehatan andalas.

[15]Donnelly LF, 2002. Correlation on Cine MR Imaging of Size of Adenoid and Palatine Tonsils with Degree of Upper Airway Motion in 
Asymptomatic Sedated Children. American Journal Radiology, 179, p. 503-7.

[16] Amalia N. 2011. Karakteristik penderita tonsilitis kronis di RSUP H. Adam Malik Medan tahun 2009. Medan: Universitas Sumatera Utara.

[17] Clough. 2011. Hubungan antara kebersihan dengan tingkat penyakit kronis dan penyakit autoimun pada wanita. Oregon State University.

[18] Khasanov SA, Asrorov AA, Vokhidov UN. 2006. Prevalence of chronic family tonsilitis and its prevention. Vestn Otorinolaryngology. $\mathrm{P} ; 4: 38$ 40.

[19] Shirley WP, Wolley AL, Wiatrak BJ. 2010. Pharyngitis and adenotonsillar disease. Dalam: Cummings Otolaryngology Head \& Neck Surgery. Philadelphia: Mosby Elsevier. hlm. 2784-5.

[20]Fakh IM, dkk. 2016. Karakteristik Pasien Tonsilitis Kronis pada Anak di Bagian THT-KL RSUP Dr. M. Djamil Padang Tahun 2013. FK Unand

[21] Kisve et all. 2009. Ear, Nose and Throat in Paediatric Patients at Rural Hospital in India. Australian Medical Journal,3, 12, p: 786-90.

[22] Susanti E. 2013. Perbedaan asupan energi, protein berdasarkan jenis kelamin, tipe daerah dan pendapatan pada remaja usia 13-18 tahun di Propinsi Nusa Tenggara Timur dan Sulawesi Tengah (Analisis Data Riskesdas Tahun 2010). Program Studi Ilmu Gizi, Fakultas Ilmu-Ilmu Kesehatan, Universitas Esa Unggul.

[23] Akcay A, Kara CO, Dagdeviren E, Zencir M. 2006. Variation in tonsil size in 4 to 17 year old school children. The Journal of Otolaryngology. P: 35(4):270-4.

[24]Farokah. 2005. Hubungan tonsilitis kronik dengan prestasi belajar pada siswa kelas II sekolah dasar di Kota Semarang. Semarang: Fakultas Kedokteran Universitas Diponegoro.

[25] National Health Service. Tonsillitis. 2010. Tersedia dari: URL: HYPER LINK http://www.nhs.uk/Conditions/Tonsillitis.

[26] Ugras Serdar, Kutluhan Ahmet. 2008. Chronic Tonsilitiis Can Be Diagnosed With Histopatologic Findings. Europe Journal General Medical. P : 95-103.

[27] Plank L. 2016. Tonsillitis, Chronic, in: volavsek M. (eds) head and neck pathology. Encyclopedia of pathology. Springger, Cham.

[28] Pinti M, Appay V, Campisi J, Frasca D, Fulop T, Sauce D, et al. 2016. Aging of the immune system: focus on inflammation and vaccination. European journal of immunology; 46 (10) : 2286301.

[29] Srikandi NM, Sutanegara SW, Sucipta IW. 2013. Profil Pembesaran Tonsil Pada Pasien Tonsilitis Kronis Yang Menjalani Tonsilektomi Di RSUP SANGLAH Pada Tahun 2013.
[30] Pejcic A, Obradivic R, Kesic L, Kojovic D. 2007. Smoking And Periodontal Disease: A Review. Medicine and Biology, 14(2): 53 - 9

[31] Aditama TY. 1997. Rokok dan Kesehatan. Jakarta: UI Press, 17-25

Email : heme@unbrah.ac.id 